\title{
POTENTIAL PITFALLS OF POLLEN DATING
}

\author{
Thomas Neulieb ${ }^{1} \bullet$ Elisabeth Levac $^{1,2} \bullet$ John Southon $^{3} \bullet$ Michael Lewis $^{4} \bullet$ I Florin Pendea $^{5} \bullet$ \\ Gail L Chmura ${ }^{1}$
}

ABSTRACT. Pollen extracted from ocean and wetland sediments cored from the eastern Canadian Margin, James Bay region, and Atlantic provinces of Canada have been radiocarbon dated and results are reported here. Pollen dates from ocean sediments were compared with marine carbonate (mollusk shells or foraminifera) dates from the same core levels, dates for which validity was assessed via correlations with other cores, and for which reworking has been excluded. Pollen samples from 3 tidal wetlands were taken from levels dated with ${ }^{137} \mathrm{Cs}$ and ${ }^{210} \mathrm{~Pb}$ profiles. Pollen dates from 2 additional wetlands were compared with ${ }^{14} \mathrm{C}$ dates of botanical macrofossils. Most pollen dates disagree with ${ }^{14} \mathrm{C}$ dates based on macrofossils or carbonates, with age differences typically exceeding $250 \mathrm{yr}$ and reaching $4000 \mathrm{yr}$ in one instance. In some cores, pollen dates show age reversals. Significant proportions of reworked pollen grains in ocean and wetland samples are associated with pollen dates that are too old. Prolonged core storage could result in pollen ${ }^{14} \mathrm{C}$ ages that are too young, possibly because of growth of fungi or other microbes, but more work is needed to verify this hypothesis. Despite the problems we encountered, some pollen dates are consistent with other ${ }^{14} \mathrm{C}$ dates from the same core levels, suggesting this dating method can work, but at present, more work is needed to understand the conflicting results obtained.

\section{INTRODUCTION}

Brown et al. $(1989,1992)$ established the validity of radiocarbon dating pollen by comparing accelerator mass spectrometry (AMS) ${ }^{14} \mathrm{C}$ dates on bulk sediments to pollen concentrates obtained from lake sediments associated with the Mazama Ash. They found pollen dates were consistent with published dates. However, Brown et al. $(1989,1992)$ also noted the presence of residual organic material in the pollen concentrates and warned this could bias results, as found with Lake Gościąż (Poland) pollen concentrates (Kilian et al. 2002). Pollen dating was tested successfully with Chinese loess-paleosol sediments (Zhou et al. 1999) on all samples from undisturbed sediment layers. Other methods subsequently were applied to obtain pure pollen samples for dating. To remove all the nonpollen material, Long et al. (1992) proposed to use a glass needle and a micromanipulator, a nonstandard and expensive equipment. Regnell and Everitt (1996), who tested heavy liquid separation with cesium chloride to isolate pollen from other material, cautioned that pollen density varied with the type of chemical processing and its source environment. Microbial digestion was tested as a means to eliminate coarse fibrous fragments from peat samples, but this was time consuming and failed to remove all non-pollen material (Richardson and Hall 1994).

Mensing and Southon (1999) reported a simple and inexpensive method to obtain pollen for ${ }^{14} \mathrm{C}$ dating. Instead of removing unwanted material through chemical or microbial processes, they employed a mouth pipetting system to pick the pollen grains. They tested their method on sediments from Lake Moran in California, and obtained good results for sediments taken below and above the Mazama Ash layer. Pollen grain concentrates were used to date syngenetic ice wedges, in an attempt

\footnotetext{
${ }^{1}$ Geography Department and Global Environmental and Climate Change Centre, McGill University, 805 Sherbrooke Street West, Montreal, Quebec H3A 0B9, Canada.

${ }^{2}$ Department of Environmental Studies, Bishop's University, 2600 College Street, Sherbrooke, Quebec J1M 1Z7, Canada. Corresponding author. Email: elevac@ubishops.ca.

${ }^{3}$ Earth System Science Department, University of California, B321 Croul Hall, Irvine, California 92697-3100, USA.

${ }^{4}$ Geological Survey of Canada Atlantic, Natural Resources Canada, Bedford Institute of Oceanography, Box 1006, Dartmouth, Nova Scotia B2Y 4A2, Canada.

${ }^{5}$ Department of Interdisciplinary Studies, Lakehead University - Orillia Campus, 500 University Avenue, Orillia, Ontario L3V0B9, Canada.
}

(C) 2013 by the Arizona Board of Regents on behalf of the University of Arizona Proceedings of the 21st International Radiocarbon Conference edited by A J T Jull \& C Hatté RADIOCARBON, Vol 55, Nr 2-3, 2013, p 1142-1155 


\section{T Neulieb et al.}

to develop an alternative method to date permafrost formations. The accuracy of ${ }^{14} \mathrm{C}$ dates appears to vary in different parts of a single ice wedge, reflecting changing proportions of in situ and redeposited pollen and spores (Vasil'chuk 2004; Vasil'chuk et al. 2004).

${ }^{14} \mathrm{C}$ dating of pollen grains has been unsuccessful with ocean sediments. Mensing and Southon (1999) attempted to date ocean samples of known calendar ages (varves) from the Santa Barbara Basin. Pollen dates for samples corresponding to the peak in nuclear testing contained, as expected, excess ${ }^{14} \mathrm{C}$ but lower levels than expected. Similarly, pollen dates for samples prior to the bomb peak were much too old, suggesting contamination by old residual carbon or the presence of reworked pollen grains.

In this study, we date pollen grains from tidal wetland deposits, a type of deposit where Mensing and Southon's (1999) method has not yet been tested. ${ }^{14} \mathrm{C}$-dated pollen from shallow depths in tidal marshes are compared with age models derived from ${ }^{137} \mathrm{Cs}$ and ${ }^{210} \mathrm{~Pb}$ profiles, while ${ }^{14} \mathrm{C}$ dates from botanical macrofossils are used for buried wetland deposits. We also test the ability of the method to date early Holocene ocean sediment samples. Older oceanic samples were selected to avoid the Suess effect (Bard 1988) responsible for the introduction of large amounts of ${ }^{14} \mathrm{C}$-depleted $\mathrm{CO}_{2}$ in the atmospheric reservoir and to avoid the impact of bomb ${ }^{14} \mathrm{C}$ from atmospheric nuclear tests (Bowman 1990; Higham 2006). ${ }^{14} \mathrm{C}$-dated pollen are compared with marine carbonate dates.

Despite the remote distance from vegetation, the ${ }^{14} \mathrm{C}$ content of pollen grains collected in ocean sediment is expected to reflect that of the atmosphere at the time of deposition. Long-distance eolian transport of pollen towards the continental shelf off eastern Canada is well documented (Mudie 1982; Levac 2012). Many studies have shown that deposition of fine-grained organic material (including pollen grains) is mediated by flocculation (Alldredge and Silver 1988) and inclusion in fecal pellets by zooplankton (Hinga et al. 1979) or mollusks (Chmura and Eisma 1995). Where bottom currents are weak, conifer pollen is probably deposited within $12 \mathrm{hr}$ (Mudie and McCarthy 1994). Pollen deposition patterns in tidal flats and salt marshes from the Netherlands and Bay of Fundy suggest that salt marshes act as sinks for pollen from local vegetation and for pollen transported by flood tides (Chmura and Eisma 1995; Beecher and Chmura 2004).

\section{METHODS}

\section{Sample Selection}

Pollen dates from shallow tidal wetland deposits were compared to age models based on profiles of ${ }^{137} \mathrm{Cs}$ and ${ }^{210} \mathrm{~Pb}$ in those deposits. Tidal wetland samples were obtained from cores recovered from the coast of James Bay, QC (AMC core $52.78^{\circ} \mathrm{N}, 78.48^{\circ} \mathrm{W}$ ); Malpeque Bay, PEI $\left(46.47^{\circ} \mathrm{N}\right.$, $\left.63.28^{\circ} \mathrm{W}\right)$; and Kouchibouguacis Lagoon, NB $\left(47.08^{\circ} \mathrm{N}, 64.28^{\circ} \mathrm{W}\right)$ (Figure 1), selected for the availability of reliable age models and minimal bioturbation within the last $100 \mathrm{yr}$, as suggested by the ${ }^{210} \mathrm{~Pb}$ profiles (Figure 2, Pendea and Chmura 2012). In the Malpeque and Kouchibouguacis cores, samples for pollen dating were taken from depths corresponding to the peak levels in ${ }^{137} \mathrm{Cs}$ (atmospherically deposited during nuclear weapons testing from 1960-1963) and to depths located before the first nuclear bombs (1933 or 1939).

Another set of pollen dates was compared to dates obtained from botanical macrofossils identified in buried wetland deposits near the eastern coast of James Bay, QC (Figure 1). Cores W25 $\left(52.98^{\circ} \mathrm{N}\right.$, $\left.78.48^{\circ} \mathrm{W}\right)$ and $\mathrm{W} 55\left(53.02^{\circ} \mathrm{N}, 78.17^{\circ} \mathrm{W}\right)$ were retrieved as part of a study of wetland evolution during isostatic rebound (Pendea et al. 2010). Both cores contain marine clay at their base and deposits of wetlands that reflect decreasing influence of tidal flooding and surface water inputs upwards: 


\section{Potential Pitfalls of Pollen Dating}

tidal marsh, tidal fen, fen, and eventually bog. The cores presented normal age-depth profiles suggesting minimal reworking or other forms of sediment disturbance (Pendea 2011).
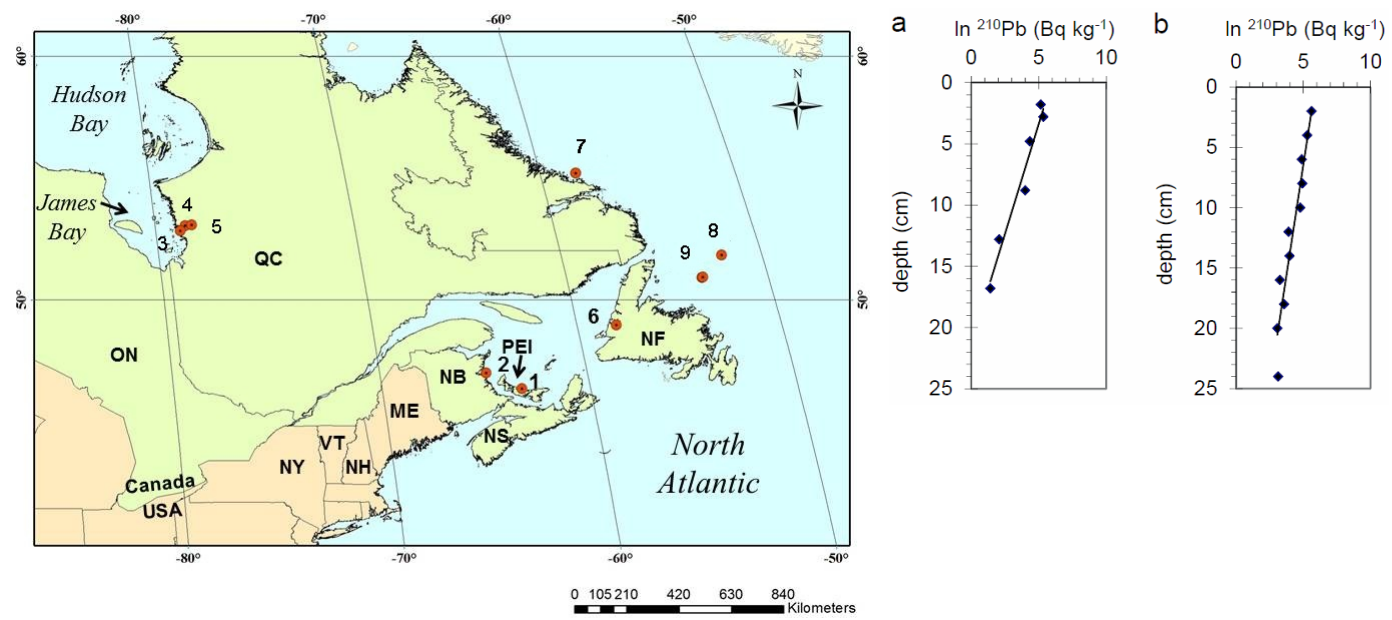

Figure 1 Location of cores used in this study: 1) Malpeque Bay, PEI; 2) Figure 2 Profiles of ${ }^{210} \mathrm{~Pb}$ in sediments cored Kouchibouguacis, NB; 3) Southeastern James Bay core AMC; 4) Southeastern from a) Malpeque Bay, PEI and b) KouchiJames Bay core W25; 5) Southeastern James Bay core W55; 6) Bay of Islands bouguacis Lagoon, NB (from Chmura 2001). core MD99-2225; 7) Inner Makkovik Bank cores 2005033B-21PC and 2005033B-22PC; 8) Notre Dame Channel core 2010023-11PC; 9) Notre Dame Channel cores 83033-07PC and 87033-19PC.

Ocean sediment samples used in this study were from cores retrieved along the eastern Canadian Margin in which ${ }^{14} \mathrm{C}$ dates were already available from shells or foraminifera (Figure 1). The Bay of Islands core, composed of silty clay mud, was retrieved from $104 \mathrm{~m}$ water depth in a fjord on the western coast of Newfoundland $\left(49.00^{\circ} \mathrm{N}, 58.08^{\circ} \mathrm{W}\right)$. Two cores of silty sandy mud of the early Holocene Qeovik Silt unit (Josenhans et al. 1986) are from the inner marginal trough of the central Labrador Shelf. The inner Makkovik Bank core 2005033B-21PC $\left(55.13^{\circ} \mathrm{N}, 58.08^{\circ} \mathrm{W}\right)$ was retrieved from $246 \mathrm{~m}$ water depth and core $2005033 \mathrm{~B}-22 \mathrm{PC}\left(55.12^{\circ} \mathrm{N}, 58.08^{\circ} \mathrm{W}\right)$ from $331 \mathrm{~m}$ water depth. Other cores spanning the equivalent sequence of sediments (Dale and Haworth 1979; Josenhans and Fader 1989) are from Notre Dame Channel (2010023-11PC at $51.79^{\circ} \mathrm{N}, 52.02^{\circ} \mathrm{W}$ from $498 \mathrm{~m}$ water depth; HU83033-07P at $50.89^{\circ} \mathrm{N}, 53.30^{\circ} \mathrm{W}$ from $457 \mathrm{~m}$ water depth and HU87033-19P at $50.91^{\circ} \mathrm{N}$, $53.26^{\circ} \mathrm{W}$ from $453 \mathrm{~m}$ water depth). Only cores with good sedimentological descriptions and undisturbed sequences were selected. Previous sedimentological, micropaleontological, or palynological studies provided additional age models for the cores from Bay of Islands (Levac 2003; Sandercombe 2011) and Notre Dame Channel (Levac et al. 2011; Lewis et al. 2012). As much as possible, we chose recent cores kept in cold storage $\left(4^{\circ} \mathrm{C}\right)$ to avoid preservation problems, with the exception of core 83033-07, initially kept in cold storage but which then spent $18 \mathrm{yr}$ in warm storage $\left(\sim 20^{\circ} \mathrm{C}\right)$.

\section{Pollen Extraction}

Pollen was extracted using the procedure reported by Levac et al. (2011). Sediments were initially sieved at $120 \mu \mathrm{m}$ to remove the coarsest particles and at $10 \mu \mathrm{m}$ to remove fine silt and clay. The remaining $10-120 \mu \mathrm{m}$ fraction was processed with cold $10 \%$ hydrochloric acid to remove carbonates and with cold $50 \%$ hydrofluoric acid to remove silicates. We avoided using alkaline treatments and acetolysis that are often used in pollen preparations, to minimize input of exogenous carbon. To further reduce the risks of contamination by ${ }^{14} \mathrm{C}$-free material, only new Nitex ${ }^{\circledR}$ sieves and new test 


\section{T Neulieb et al.}

tubes made of non-reactive material were used. To rule out contamination from within the laboratories (at McGill and at Bishop's universities), we attempted without success to extract ${ }^{14} \mathrm{C}$-free pollen from Sangamonian sediments to determine the modern carbon blank for the pollen extraction process. As an alternative, size-dependent ${ }^{14} \mathrm{C}$ backgrounds were determined on small aliquots of coal dust that had undergone the pollen extraction chemistry (Table 1), as well as the AMS sample preparation procedures. Based on these results, plus measurements of small aliquots of the modern OXI standard, small-sample corrections for blanks of $0.4 \pm 0.2 \mu \mathrm{g}$ of both modern and ${ }^{14} \mathrm{C}$-free carbon were applied to the pollen results. To derive these estimates, the results for small ${ }^{14} \mathrm{C}$-free and modern (contemporary) test samples were plotted on log-log plots of background vs. sample size, similar to those in Figures 9 and 10 of Santos et al. (2007), and the resulting estimates of modern and ${ }^{14} \mathrm{C}$ free contamination were obtained directly from the plots. Mass balance (i.e. size-dependent) corrections were then applied to the unknowns based on Equation 5 of Santos et al. 2007. (See Appendix A of that paper for a detailed derivation.) An uncertainty of 50\% was applied to all of the background corrections, based on the run-to-run scatter commonly observed in small sample blanks.

Table 1 Aliquots of powdered coal subjected to the pollen chemistry plus combustion, graphitization, and AMS measurement at UC Irvine to determine potential contamination during lab processing of samples.

\begin{tabular}{lllll}
\hline $\begin{array}{l}\text { UCIAMS } \\
\text { Lab \# }\end{array}$ & $\begin{array}{l}\text { Weight } \\
(\mathrm{mg} \mathrm{C})\end{array}$ & $\begin{array}{l}\text { Fraction Modern } \\
(\mathrm{Fm})\end{array}$ & $\Delta^{14} \mathrm{C}(\%)$ & ${ }^{14} \mathrm{C}$ age (BP) \\
\hline \multicolumn{5}{l}{ Bishop's University blanks } \\
105028 & 0.530 & $0.0016 \pm 0.0001$ & $-998.4 \pm 0.1$ & $51,750 \pm 260$ \\
105029 & 0.170 & $0.0022 \pm 0.0001$ & $-997.8 \pm 0.1$ & $49,220 \pm 290$ \\
105030 & 0.038 & $0.0074 \pm 0.0003$ & $-992.5 \pm 0.3$ & $39,350 \pm 280$ \\
\multicolumn{1}{l}{ McGill University blanks } & & & \\
105031 & 0.075 & $0.0043 \pm 0.0002$ & $-995.7 \pm 0.2$ & $43,720 \pm 430$ \\
105032 & 0.025 & $0.0137 \pm 0.0004$ & $-986.3 \pm 0.4$ & $34,450 \pm 250$ \\
105033 & 0.056 & $0.0083 \pm 0.0002$ & $-991.7 \pm 0.2$ & $38,520 \pm 230$ \\
\hline
\end{tabular}

Pollen grains were isolated from the processed samples following the method of Mensing and Southon (1999). Conifer pollen (primarily pine, Pinus, and spruce, Picea) were identified and picked using a binocular microscope at 35-50× magnification after careful washing over a 10- $\mu \mathrm{m}$ sieve. We selected these taxa because they constitute 40 to $70 \%$ of pollen assemblages in sediments of the eastern Canadian Margin (Mudie and McCarthy 1994) and they are readily transported by wind (Mudie 1982). Between 200-2000 pollen grains were picked, depending on the pollen concentrations in the samples. These numbers provided sufficient carbon weight to obtain a ${ }^{14} \mathrm{C}$ date with most of the samples (17 out of 19) due to the large size of the conifer pollen, which also makes them easier to target. The extracted pollen samples were dated at the Keck Carbon Cycle AMS facility at the University of California, Irvine (Southon et al. 2004) using standard small-sample techniques (Santos et al. 2007). All ${ }^{14} \mathrm{C}$ ages shown are conventional ${ }^{14} \mathrm{C}$ ages corrected for isotopic fractionation and calculated according to Stuiver and Polach (1977). Large $1 \sigma$ errors for some of the results primarily reflect increased uncertainties in the determination of backgrounds for very small samples.

We dated samples of modern pine pollen (Pinus massoniana) that were purchased from a health food store in late 2012 and treated with base plus acid, and base plus acid plus chlorine bleach, to remove waxy coatings and the interior cytoplasm, leaving the exine (outer shell) which remains in fossil pollen. These gave Fm values of $1.037 \pm 0.002$ and $1.035 \pm 0.002$, respectively, close to 20112012 atmospheric ${ }^{14} \mathrm{CO}_{2}$ results (X Xu, personal communication), indicating that the ${ }^{14} \mathrm{C}$ content of pollen does indeed reflect that of the contemporary atmosphere. 


\section{Radiocarbon Calibration}

The ${ }^{14} \mathrm{C}$ dates were calibrated to correct for variations in atmospheric ${ }^{14} \mathrm{C}$ concentration over time. Pollen dates were calibrated with the calibration program CALIB v 6.1.1 (http://calib.qub.ac.uk/) using the IntCal09 calibration data set, while shells or foraminifera dates were calibrated using the Marine09 calibration curve (Reimer et al. 2009).

Normally, 2 corrections are applied to marine carbonate dates: the global ocean reservoir correction ( $\sim 400 \mathrm{yr}$ ), to account for the global offset from the IntCal09 curve (Stuiver et al. 2005; Reimer et al. 2009), and a regional $\Delta \mathrm{R}$ correction to account for any additional offset for the specific study area (Stuiver et al. 2005; Reimer et al. 2009). In the Marine Reservoir Correction Database at Queen's University, Belfast (Stuiver et al. 2012), the sites that are the closest to our core sites call for regional corrections between 60-150 yr (McNeely et al. 2006). In addition, where appropriate, we added a 100- to 200-yr correction to account for deglacial/early Holocene sea ice conditions for the respective study regions, using the model developed by Bard et al. (1994) (see Lewis et al. 2012). The corrections for increased sea ice duration have an uncertainty of \pm 50 based on the precision (1.28 months) of the method used for the sea ice reconstructions (Levac 2002) upon which the sea ice corrections are based. This sea ice correction has been added to the $\Delta \mathrm{R}$ before the calibrations.

Calibrated ${ }^{14} \mathrm{C}$ dates are reported in cal $\mathrm{BP}$ within a $2 \sigma$ range and corresponding $95 \%$ confidence interval. All the calibrated age ranges are reported in Tables 2, 3, and 4, but ranges with the highest probabilities are reported in the discussion. The ages from ${ }^{14} \mathrm{C}$-dated pollen from the modern tidal marshes (Table 2) were compared with the ${ }^{210} \mathrm{~Pb}$ - and ${ }^{137} \mathrm{Cs}$-derived calendar years, or the fraction Modern values $\left(\mathrm{F}^{14} \mathrm{C}\right.$ : Reimer et al. 2004) obtained with CALIBomb (Reimer and Reimer 2005) for post-bomb data.

\section{RESULTS AND DISCUSSION}

\section{Wetlands}

Tidal wetland samples produced ${ }^{14} \mathrm{C}$ pollen data that disagreed with the results based on the ${ }^{137} \mathrm{Cs}$ and ${ }^{210} \mathrm{~Pb}$ profiles (Table 2). The pollen sample from $13.2 \mathrm{~cm}$ in the Malpeque Bay core returned a Fm value of 1.17, but this level is characterized by a ${ }^{137} \mathrm{Cs}$ peak and therefore corresponds to $1963 \mathrm{yr}$ $\mathrm{CE}$, for which $\mathrm{F}^{14} \mathrm{C}$ ranged from 1.5 to 2.0 for the high-latitude Northern Hemisphere (Hua and Barbetti 2004). We obtained a similarly discrepant result for the $1960 \mathrm{yr}$ CE sample from the Kouchibouguacis core, for which the pollen sample returned a $\mathrm{F}^{14} \mathrm{C}$ value of 1.025 , much lower than the expected value of 1.22. Mensing and Southon (1999) also found surprisingly low $\mathrm{F}^{14} \mathrm{C}$ results for Santa Barbara Basin pollen samples from the 1960s.

Two other samples from these same deposits were from levels predating the nuclear bomb. In the Malpeque Bay core, the $22.2 \mathrm{~cm}$ depth has a pollen date of $530 \pm 70 \mathrm{BP}$ compared to the ${ }^{210} \mathrm{~Pb}$ derived date of $1939 \mathrm{yr} \mathrm{CE}$, which corresponds to a ${ }^{14} \mathrm{C}$ age of $170 \mathrm{BP}$ on the IntCal09 curve. Similarly, at $21.5-22.5 \mathrm{~cm}$ depth in the Kouchibouguacis core, the date for pollen is $700 \pm 100 \mathrm{BP}$, whereas the ${ }^{210} \mathrm{~Pb}$-derived date of $1933 \mathrm{yr} \mathrm{CE}$ yields an equivalent ${ }^{14} \mathrm{C}$ age of $150 \mathrm{BP}$. These differences cannot be explained by the Suess effect (the ${ }^{14} \mathrm{C}$ depletions due to the introduction of fossil fuel carbon dioxide into the atmosphere) since those depletions are already built into the calibration curve. Instead, we believe they are due to the presence in our samples of reworked pollen, which could introduce ${ }^{14} \mathrm{C}$-depleted carbon into both pre- and post-bomb samples. Roe and van de Plassche (2005) studied pollen in a Connecticut salt marsh and found that the pollen can be eroded from older local sediments before being redeposited nearby. This process would not be visible min- 
T Neulieb et al.

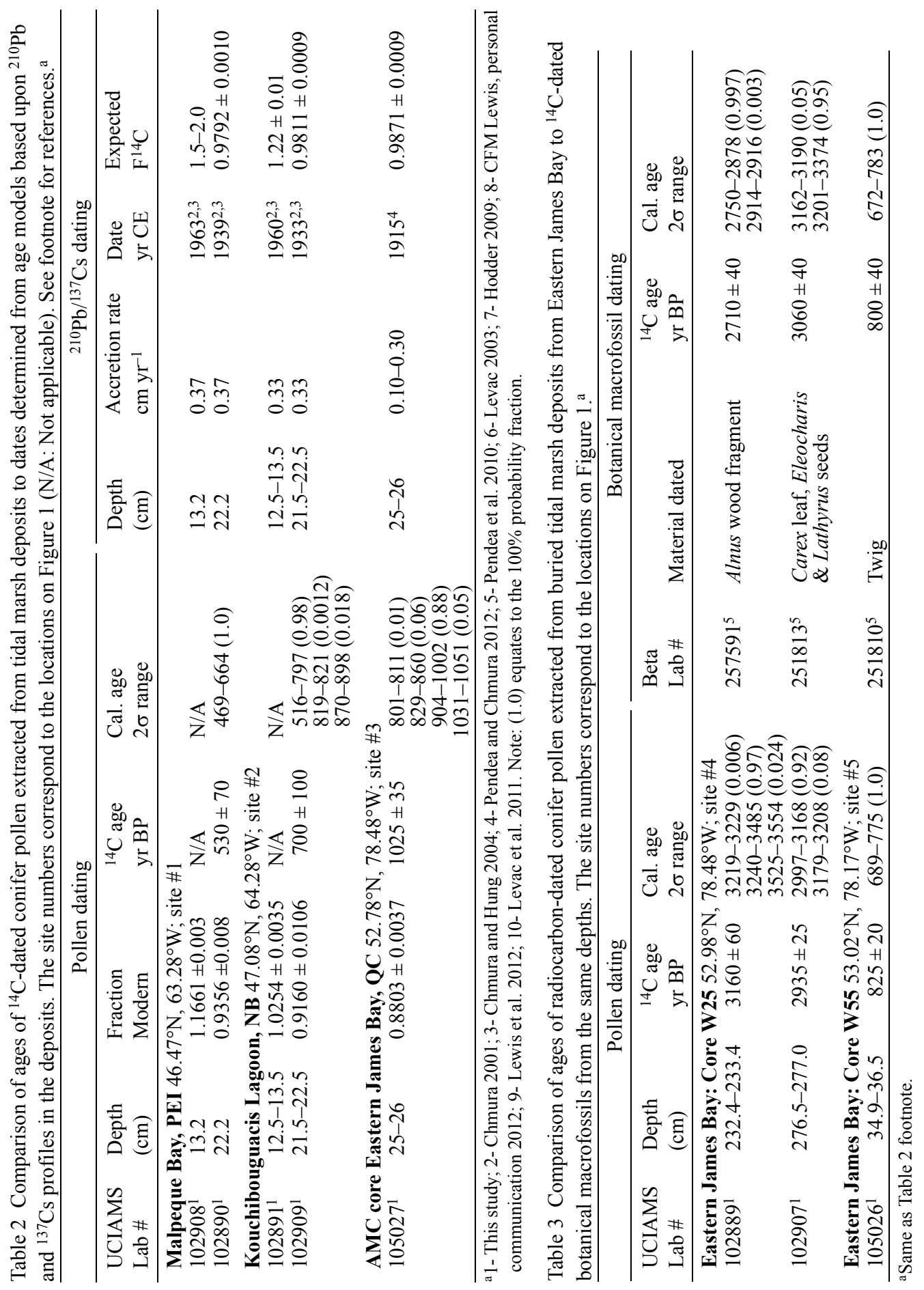


eralogically. Residues from the pollen extraction were mounted on slides and examined at $400 \times$ magnification. The condition of each grain was recorded, and grains exhibiting deterioration, as displayed in Figure 3, were considered reworked. The examination revealed that at $21.5-22.5 \mathrm{~cm}$ depth Malpeque Bay sediment contained 22\% reworked pollen and at $22.2 \mathrm{~cm}$ depth Kouchibouguacis sediment contained $15 \%$ reworked pollen. From this, we suspect that, despite careful picking, reworked conifer pollen was included in the samples sent for ${ }^{14} \mathrm{C}$ dating. In the $\mathrm{AMC}$ core from southeastern James Bay, the ${ }^{14} \mathrm{C}$ age of pollen from $25-26 \mathrm{~cm}$ depth is $1025 \pm 35 \mathrm{BP}$, much older than the ${ }^{210} \mathrm{~Pb}$-derived age. We suspect pollen reworking, but this was not verified for this sample.

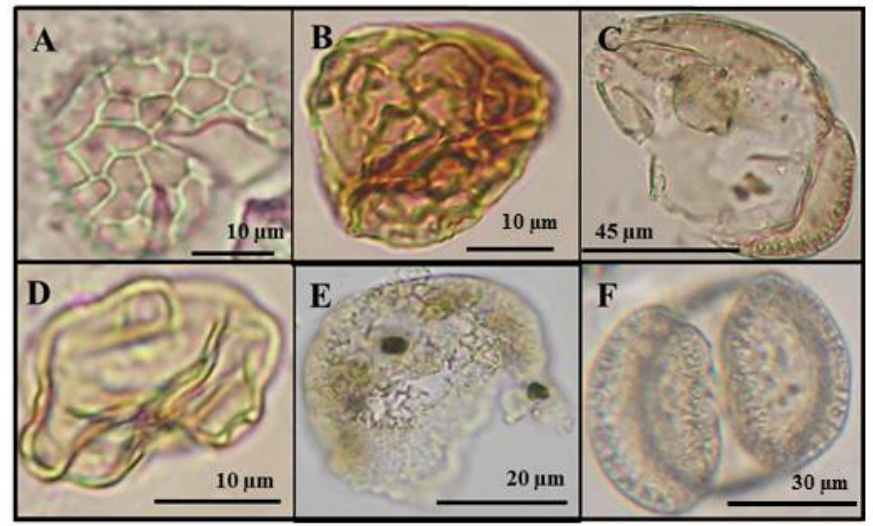

Figure 3 Microphotographs of pollen grains showing different types of deterioration based on categories of Birks and Birks (1980): A) Broken Lycopodium spore, $957 \mathrm{~cm}$ depth, core 2005033B-21PC; B) Degraded Lycopodium spore showing increase in opacity, $565-566 \mathrm{~cm}$ depth, core 2005033B-22PC: C) Broken bisaccate pollen, with $1 / 2$ remaining, 565-566 cm depth, core 2005033B22PC;. D) Crumpled and folded Betula pollen, $957 \mathrm{~cm}$, core 2005033B-21PC; E) Broken bisaccate pollen with 1/3 remaining; F) Non-degraded bisaccate pollen, $957 \mathrm{~cm}$, core 2005033B-21PC.

The James Bay wetland cores with ${ }^{14} \mathrm{C}$-dated botanical macrofossils produced ${ }^{14} \mathrm{C}$ pollen dates that are either similar or older than those from macrofossils (Table 3). In core W25, pollen grains from the depth interval $232.4-233.4 \mathrm{~cm}$ returned ages of $3160 \pm 60 \mathrm{BP}$, older than the macrofossil ${ }^{14} \mathrm{C}$ date of $2710 \pm 40$ BP. Examination of the pollen residue revealed $31 \%$ reworked pollen. That depth interval represents a minerotrophic fen, a wetland receiving surface water input (Shotyk 1996), a process that could have introduced some old pollen grains in the $232.4-233.4 \mathrm{~cm}$ interval. Blaauw et al. (2004) has assessed the robustness of ${ }^{14} \mathrm{C}$ dating of various types of plant remains and it is unlikely that the problem lies there. At Lake Gościąż (Poland), macrofossil ${ }^{14} \mathrm{C}$ dates from laminated sediments would match the varve chronology, while ${ }^{14} \mathrm{C}$ dates from pollen were too old (Kilian et al. 2002). We note, however, that the dates were based on pollen concentrates ( $80 \%$ pollen), and could be biased by organic material other than pollen.

At a lower depth (276.5-277 cm) in James Bay core W25, the pollen age of $2935 \pm 25$ BP is younger than the macrofossil age of $3060 \pm 40 \mathrm{BP}$, but by only $125 \mathrm{yr}$. The calibrated age ranges with the highest probabilities do not show any overlap. However, if we use the lower of the 2 values, as advocated by Pendea et al. (2010) on stratigraphic grounds, the macrofossil and pollen calibrated date ranges for this interval (3162-3190 versus 2997-3168 cal BP) overlap. That depth interval in core W25 represents the transition from a tidal marsh stage to a fen stage; hence we could expect a slight 


\section{T Neulieb et al.}

tidal influence and potentially some pollen redeposition. However, this is apparently not always the case. In core W55, pollen and macrofossil ${ }^{14} \mathrm{C}$ dates for the depth interval $34.9-36.5 \mathrm{~cm}$ are close, $825 \pm 20$ and $800 \pm 40 \mathrm{BP}$, and their calibrated age ranges overlap.

\section{Ocean Sediments}

Few of the pollen samples returned ${ }^{14} \mathrm{C}$ dates that were in agreement with the ${ }^{14} \mathrm{C}$ dates from the marine carbonate samples (Table 4). Many pollen samples returned dates that are considerably older or younger (by 1000-4000 yr), sometimes within the same core. The pollen ages showing agreement with the marine carbonate dates are from Notre Dame Channel (core 2010023-11 and 8703319) and Makkovik Bank (core 2005033-22PC). Differences in age range between 70 and $250 \mathrm{yr}$. In core 2010023-11, the pollen age is $11,310 \pm 180 \mathrm{BP}$ and the age based on foraminifera is $11,765 \pm$ $25 \mathrm{BP}$, resulting in an age difference of $250{ }^{14} \mathrm{C}$ yr, but the calibrated $2 \sigma$ range for pollen $(12,720$ 13,511 cal BP) overlaps that of the foraminifera (12,692-13,095 cal BP). In core 87033-19, 1 pollen age appears to be in agreement with ${ }^{14} \mathrm{C}$ based on foraminifera. The pollen sample at $778-779 \mathrm{~cm}$ returned an age of 10,280 $\pm 60 \mathrm{BP}$, right between the planktonic age of 10,175 $\pm 25 \mathrm{BP}$ and the benthic age of $10,450 \pm 30 \mathrm{BP}$. After calibration, however, the pollen age is older than the 2 foram dates (Table 4). We also note that the pollen age at $778-779 \mathrm{~cm}$ is older than the pollen age at 874$877 \mathrm{~cm}$. In core 2005033-22, the pollen and shell ages are close (respectively, $6700 \pm 190 \mathrm{BP}$ and $7150 \pm 40 \mathrm{BP}$ ), and their calibrated age ranges are not statistically distinguishable (7255-7937 versus $7347-7626$ cal BP).

All 3 pollen samples from core 2005033B-21PC from the Inner Marginal Trough near Makkovik Bank returned dates older than the marine carbonate samples. In the $755-756 \mathrm{~cm}$ depth interval, the pollen date is $8070 \pm 80 \mathrm{BP}$ while the marine carbonate date is $6970 \pm 40 \mathrm{BP}$. At $957 \mathrm{~cm}$, the pollen date is $9060 \pm 130 \mathrm{BP}$ and the marine carbonate is $7135 \pm 20 \mathrm{BP}$. Finally, at $1038 \mathrm{~cm}$ the pollen date is $8680 \pm 120 \mathrm{BP}$ and the marine carbonate is $7150 \pm 20 \mathrm{BP}$.

The pollen ages that are apparently too young are from different cores as well (core MD99-2225, 83033-07, and 87033-19). The pollen sample from core MD99-2225 at 1440-1442 cm is dated at $7030 \pm 100$, while the bivalve shell has a date of $9120 \pm 90$ BP. The 2 pollen samples from core 83033-7 are a few thousand years younger than the ages based on foraminifera. At $65-67 \mathrm{~cm}$, the pollen sample is dated at $4360 \pm 70 \mathrm{BP}$, while the planktonic foraminifera are dated at $8390 \pm$ $100 \mathrm{BP}$. At $217-218 \mathrm{~cm}$, the pollen age is $6580 \pm 100 \mathrm{BP}$, compared with the foraminifer's age of $9520 \pm 35 \mathrm{BP}$. In core 87033-19, the pollen samples at 503-504 cm returned an age of $9150 \pm$ $220 \mathrm{BP}$, while the shell returned an age of $10,300 \pm 300 \mathrm{BP}$. At $874-877 \mathrm{~cm}$ in the same core, the pollen age is $9760 \pm 220 \mathrm{BP}$, compared with a carbonate age of 10,500 $\pm 40 \mathrm{BP}$. Calibrating the ages does not reduce the differences between pollen and carbonate ages significantly.

Finally, we have a number of pollen dates from MD99-2225 for which we do not have carbonate dates for comparison. We have pollen dates of $7760 \pm 60 \mathrm{BP}$ at $1240-1242 \mathrm{~cm}, 8330 \pm 120 \mathrm{BP}$ at $1260-1262 \mathrm{~cm}$, and $7990 \pm 450 \mathrm{BP}$ at $1430-1432 \mathrm{~cm}$. We note an age reversal with the youngest age at $1440-1442 \mathrm{~cm}$, which is unexpected.

The mixed results produced by pollen samples from the various ocean cores, and in some cases, the mixed results observed between pollen samples from the same core, render the interpretation of these results very difficult. Differential bioturbation of the sediment fractions could play a role. Because they are smaller than mollusk shells or foraminifera tests, pollen grains could be more easily bioturbated and mixed across a thicker sediment layer (Bard 2001). However, the high sedimentation rates along the eastern Canadian Margin would keep these effects to a minimum (Anderson 


\section{Potential Pitfalls of Pollen Dating}

2001; Bard 2001). Between 755 and $1038 \mathrm{~cm}$ in Makkovik Bank core 2005033-21, the sedimentation rate is $1.69 \mathrm{~cm} \mathrm{yr}^{-1}$. Sedimentation rates of similar magnitude have been calculated for other sediment cores in the region, including core 87033-19 (Levac 2002; Levac et al. 2011) and core MD99-2225 (Sandercombe 2011).

Increased duration of sea ice cover also could explain, in part, the older pollen ages. Pollen of many conifer species (such as Pinus and Picea) are easily transported by wind over long distances (Bourgeois et al. 1985; Mudie and McCarthy 1994), but extensive sea ice could delay their deposition to the sediments. This explanation is not entirely satisfactory though because some samples deposited at a time when we should expect a longer sea ice duration (such as the samples from Notre Dame Channel core 201023-11) actually returned pollen dates that are similar to the carbonate ages. It would also be difficult to explain all of the age differences with just the sea ice cover.

Another explanation for older pollen dates would be the presence of reworked pollen grains in the dated samples, as it is not possible to assess degradation at the magnification used for hand-picking. The 24-36\% degraded pollen found in the Makkovik Bank core 2005033-21 could explain why the pollen dates are markedly older than carbonate dates. In core 2005033-22, where degraded pollen grains amounts are low the pollen ${ }^{14} \mathrm{C}$ date is similar to the shell date. Mensing and Southon (1999) encountered a similar situation in the Santa Barbara Basin. There, pollen grains also appeared intact, but pollen samples returned dates that were too old. The influence of meltwater from the Laurentide Ice Sheet has been recognized in the core 2005033-21 deposits from which the pollen sample was taken (Levac et al. 2011) and the sediments transported by the meltwater plume would be expected to carry reworked pollen as well. We suspect that if pollen was redeposited from Quaternary deposits along the east coast they might not show signs of degradation. Because core 201023-11 is located further offshore, this site would have received lower inputs of reworked pollen grains from meltwater; and pollen and carbonate dates are similar. Advection of pollen and organic material in marine environments might be more common than usually believed.

Pollen reworking also could explain an age reversal in core 87033-19. The pollen age at 778-779 cm is older than the other pollen ages, and older than the marine carbonate ages. That sample was taken just above the lowest detrital carbonate layer (see Levac et al. 2011). The plume of meltwater that deposited this layer was likely originally eroded from Paleozoic age rocks and pollen- and carbonate-bearing Quaternary sediments in the Hudson Bay region, consistent with the $35 \%$ proportion of reworked pollen reported by Levac et al. (2011) at that depth. The proportion of reworked pollen is lower $(20 \%)$ at $503-504 \mathrm{~cm}$, and the pollen date is younger than the marine carbonate date, supporting the idea that high proportions of reworked pollen result in pollen dates being older. However, 1 sample from core 83033-07, collected within the detrital carbonate layer corresponding to the catastrophic drainage of Lake Agassiz (and we assume containing a high proportion of degraded pollen grains) returned a pollen date that was younger than the marine carbonate date. This suggests that factors other than reworked pollen can also affect the ${ }^{14} \mathrm{C}$ dates in some of the samples. The assumption about reworked pollen in core 83033-07 cannot be verified as we do not have palynological data for that core.

The pollen dates in MD99-2225 show an age inversion that cannot be explained by changes in lithology (Levac 2003; Sandercombe 2011) and we are confident about the shell date for that core (see below). An age reversal was also observed in the Santa Barbara Basin pollen dates (Mensing and Southon 1999). A few ocean pollen samples returned dates that were markedly younger than the dates from marine carbonates. These marine carbonate dates were obtained from different types of material (bivalve shells, planktonic and benthic foraminifera); hence, this would not explain the age 
T Neulieb et al.

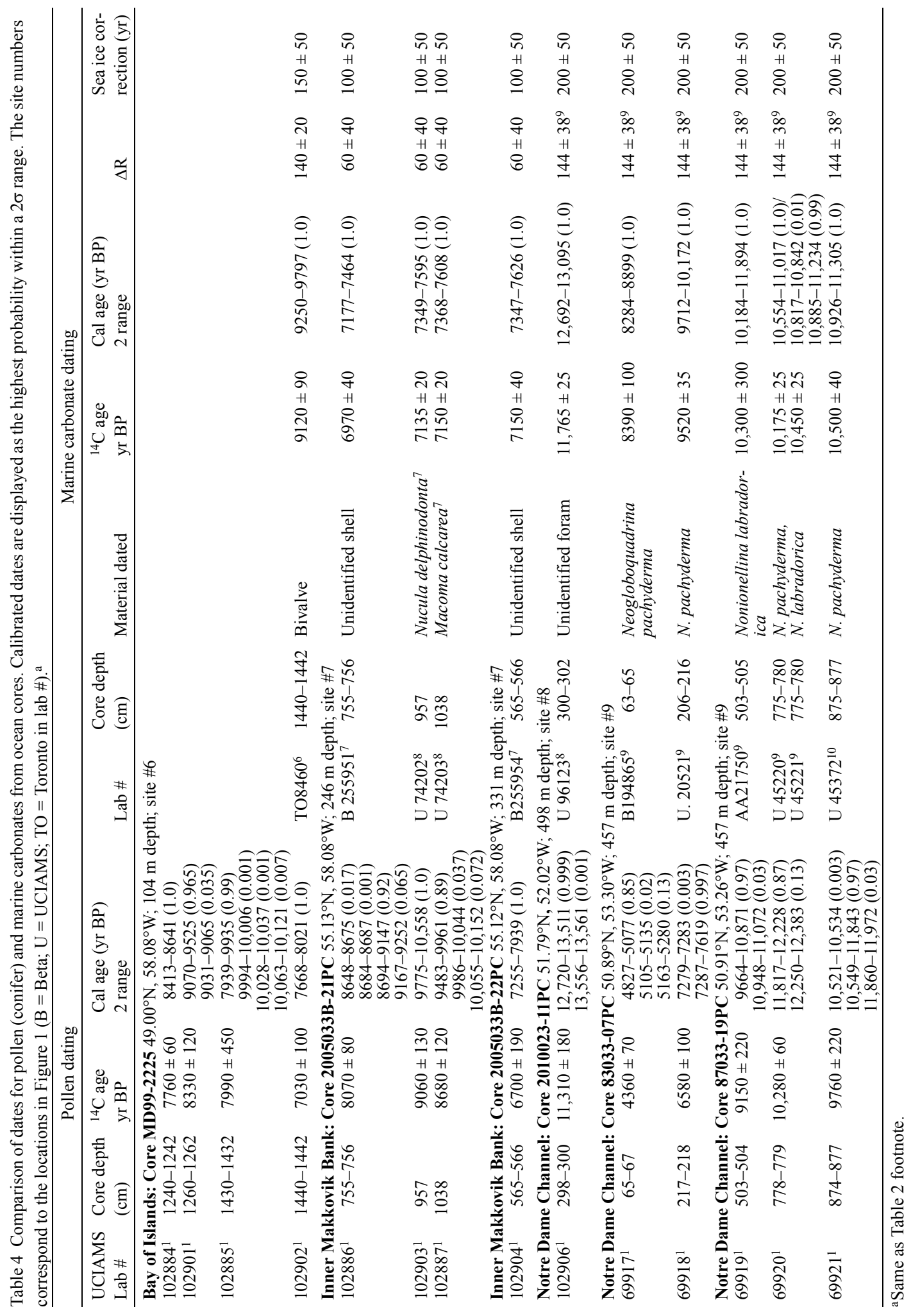


offset. Reworking of shells and foraminifera is also a possibility and we could speculate that the presence of small amounts of detrital carbonate in sediments, even at depth intervals devoid of distinct detrital carbonate layers, could nevertheless affect the marine carbonate ages and make them appear too old. These 2 hypotheses would be appealing if we were not confident about the carbonate ages for the 3 ocean cores returning younger pollen ages: cores MD99-2225, 83033-07, and 8703319.

The pollen diagram for core MD99-2225 shows a major shift in vegetation between 1500 and $1800 \mathrm{~cm}$, just below the pollen-dated level at 1440-1442 cm (Sandercombe 2011), corresponding to the Pre-boreal Oscillation (Anderson et al. 2007). The end of this event $(1500 \mathrm{~cm}$ in the core) is dated at $9620 \mathrm{cal}$ BP in nearby Southwest Brook Lake, based on a bulk sediment date of $8550 \pm$ 220 BP reported by Anderson and Lewis (1992). This is close to the carbonate date obtained at $1440 \mathrm{~cm}$, suggesting that it is the pollen date that is too young by about $1854{ }^{14} \mathrm{C} \mathrm{yr}$.

The pollen stratigraphy from 87033-19 has been correlated with pollen stratigraphies from Newfoundland lakes. The interval between 450 and $900 \mathrm{~cm}$ in core 19 corresponds to Compass Pond zone CP2-ii (Dyer 1986), which has a bulk sediment date of $9300 \mathrm{cal} \mathrm{BP}$ at the top (for details see Levac et al. 2011). While bulk sediment dates sometimes can be problematic (Grimm et al. 2009), correlations of core 19 with other dated cores from the region based on detrital carbonate layers associated with meltwater drainage episodes along the eastern Canadian Margin (Lewis et al. 2012) reinforce our confidence in the carbonate ages for core 19. There is no palynological data for core 83033-07; however, correlations with nearby core 19, also based on detrital carbonate layers (Levac et al. 2011), suggest that the marine carbonate dates available for both cores are valid. So, unless both the marine carbonate dates and the bulk sediments dates from lakes are invalid, we need another explanation for the much younger pollen dates.

The radically younger pollen ages obtained for core 83033-07 might be explained by the storage conditions. While the carbonate samples were collected shortly after the core was recovered, the pollen samples were collected after the core spent $18 \mathrm{yr}$ in warm storage. Growth by fungi or other microbes could have introduced ${ }^{14} \mathrm{C}$-rich $\mathrm{CO}_{2}$ within the samples (Wohlfarth et al. 1998), biasing the pollen ages. If this allochtonous material is removed by the pollen preparation with acids, this effect might be limited, but Kilian et al. (2002) believe that the shape and size of pollen grains might allow contaminating material to remain inside the pollen grain. Low-level ${ }^{14} \mathrm{C}$ has been used aboard ships at Bedford Institute of Oceanography to measure primary production of phytoplankton. Despite precautions in its use, and the isolation of coring activities on different expeditions, selective contamination by low-level ${ }^{14} \mathrm{C}$ is a possibility and may have contributed to the anomalously young pollen ${ }^{14} \mathrm{C}$ ages. However, research fleet operators are generally well aware of this problem and tracer spills are rare. Furthermore, any contamination incidents (i.e. with bicarbonate solutions) are likely to affect carbonate samples even more than the pollen grains, given the very harsh pollen extraction chemistry (including the use of $\mathrm{HCl}$ ). This is not the case here as carbonate dates are older than the pollen dates.

\section{CONCLUSIONS}

We found that few pollen dates are in agreement with ${ }^{14} \mathrm{C}$ dates based on macrofossils or marine carbonates, or with the age models derived from ${ }^{210} \mathrm{~Pb}$ or ${ }^{137} \mathrm{Cs}$ profiles. The magnitude of the apparent aging effect that reworked pollen has on pollen dates (either from ocean or wetland cores) suggests that pollen reworking is more than just a negligible background effect. We suspect reworking might be a bigger problem than previously believed in palynological samples from ocean and wetland 


\section{T Neulieb et al.}

deposits, as it can go unnoticed due to the absence of visible signs of degradation, especially for material of Quaternary age. However, the presence of reworked pollen grains does not translate into older pollen dates for all samples, suggesting there are processes affecting pollen dates that we still do not understand. Some ocean sediment cores with multiple pollen dates show age reversals that are not observed in carbonate dates, and that are not linked with changes in lithology.

In tidal wetland cores, pollen samples from levels predating the nuclear bomb returned ages that were much too old, even if the Suess effect is taken into account. Also, these samples contained a lower modern ${ }^{14} \mathrm{C}$ fraction than expected. Pollen samples from levels corresponding to the peak in nuclear testing also contained lower $\mathrm{F}^{14} \mathrm{C}$ than expected from atmospheric saturation in ${ }^{14} \mathrm{C}$ caused by the bombs. Finally, prolonged core storage could result in pollen ${ }^{14} \mathrm{C}$ ages that are too young, possibly as a result of bacterial degradation, but more work is needed to verify this hypothesis and to explain its exact mechanisms.

\section{ACKNOWLEDGMENTS}

This work was funded by an NSERC Discovery grant (EL). TN would like to thank GEC3 of Quebec and the McGill Geography Department for graduate student stipends to support his work, Publication Grant from Bishop's University, and the GEC3 for a travel grant to attend the Radiocarbon Conference in Paris. Kate Jarrett from the Geological Survey of Canada Atlantic, is acknowledged for helping subsample the cores. Comments from 2 anonymous reviewers are greatly acknowledged.

\section{REFERENCES}

Alldredge AL, Silver MW. 1988. Characteristics, dynamics and significance of marine snow. Progress in Oceanography 20(1):41-82.

Anderson DM. 2001. Attenuation of millennial-scale events by bioturbation in marine sediments. Paleoceanography 16(4):352-7.

Anderson TW, Levac E, Lewis CFM. 2007. Cooling in the Gulf of St. Lawrence and estuary region at 9.7 to $7.2{ }^{14} \mathrm{C}$ ka (11.2-8.0 cal ka): palynological response to the PBO and 8.2 cal ka cold events, Laurentide Ice Sheet air-mass circulation and enhanced freshwater runoff. Palaeogeography, Palaeoclimatology, Palaeoecology 246(1):75-100.

Anderson TW, Lewis CFM. 1992. Climatic influences of deglacial drainage changes in southern Canada at 10 to $8 \mathrm{ka}$ suggested by pollen evidence. Géographie Physique et Quaternaire 46(3):255-72.

Bard E. 1988. Correction of accelerator mass spectrometry ${ }^{14} \mathrm{C}$ ages measured in planktonic foraminifera: paleoceanographic implications. Palaeogeography 3(6): 635-5.

Bard E. 2001. Paleoceanographic implications of the difference in deep sea sediment mixing between large and fine particles. Palaeogeography 16(3):235-9.

Bard E, Arnold M, Mangerud J, Paterne M, Labeyrie L, Duprat J, Melieres MA, Sonstegaard E, Duplessy JC. 1994. The North Atlantic atmosphere-sea surface ${ }^{14} \mathrm{C}$ gradient during the Younger Dryas climatic event. Earth and Planetary Science Letters 126(4):275-87.
Beecher CB, Chmura GL. 2004. Pollen-vegetation relationships in Bay of Fundy salt marshes. Canadian Journal of Botany 82(5):663-70.

Birks HJ, Birks HH. 1980. Quaternary Paleoecology. Baltimore: University Park Press.

Blaauw M, van der Plicht J, van Geel B. 2004. Radiocarbon dating of bulk peat samples from raised bogs: non-existence of a previously reported 'reservoir effect'? Quaternary Science Reviews 23(14-15):153742.

Bourgeois JC, Koerner RM, Alt BT. 1985. Airborne pollen: a unique air mass tracer, its influx to the Canadian High Arctic. Annals of Glaciology 7:109-16.

Bowman S. 1990. Radiocarbon Dating (Interpreting the Past. Berkeley: University of California Press.

Brown TA, Nelson DE, Mathewes RW, Vogel JS, Southon JR. 1989. Radiocarbon dating of pollen by accelerator mass spectrometry. Quaternary Research 32(2):205-12.

Brown TA, Farwell GW, Grootes PM, Schmidt FH. 1992. Radiocarbon dating of pollen extracted from peat samples. Radiocarbon 34(3):550-6.

Chmura GL. 2001. The fate of salt marshes in Atlantic Canada. Climate Change Action Fund, Natural Resources Canada. $18 \mathrm{p}$.

Chmura GL, Eisma D. 1995. A palynological study of surface and suspended sediments on a tidal flat: implications for pollen transport and deposition in coastal waters. Marine Geology 128(3-4):183-200. 


\section{Potential Pitfalls of Pollen Dating}

Chmura GL, Hung GA. 2004. Controls on salt marsh accretion: a test in salt marshes of Eastern Canada. Estuaries 27:70-81.

Dale CT, Haworth RT. 1979. High resolution seismology studies on late Quaternary sediments of the northeast Newfoundland continental shelf. Current Research, Part B, Geological Survey of Canada, Paper 79-1B. p 357-64.

Dyer AK. 1986. A palynological investigation of the late Quaternary vegetational history of the Baie Verte Peninsula, northcentral Newfoundland [Master's thesis]. Department of Geography, Memorial University of Newfoundland. 182 pages.

Grimm EC, Maher LJ, Nelson DM. 2009. The magnitude of error in conventional bulk-sediment radiocarbon dates from central North America. Quaternary Research 72:301-8.

Higham T. 2006. C14 dating: corrections [online]. Available: www.c14dating.com/corr.html [accessed September 6, 2012].

Hinga KR, Sieburth J, Heath GR. 1979. The supply and use of organic matter at the deep-sea floor. Journal of Marine Research 37:357-579.

Hodder TJ. 2009. Sediment analysis of three piston cores from the Labrador Inner Marginal Trough. Coop report to Geological Survey of Canada Atlantic/Natural Resources Canada/Bedford Institute of Oceanography.

Hua Q, Barbetti M. 2004. Review of tropospheric bomb ${ }^{14} \mathrm{C}$ data for carbon cycle modeling and age calibration purposes. Radiocarbon 46(3):1273-98.

Josenhans HW, Fader GBJ. 1989. A comparison of models of glacial sedimentation along the Eastern Canadian Margin. Marine Geology 84(2-4):273-300.

Josenhans H, Zevenhuizen J, Klassen RA. 1986. The Quaternary geology of the Labrador Shelf. Canadian Journal of Earth Sciences 23:1190-213.

Kilian MR, van der Plicht J, van Geel B, Goslar T. 2002. Problematic ${ }^{14} \mathrm{C}$-AMS dates of pollen concentrates from Lake Gościąż (Poland). Quaternary International 88:21-6.

Levac E. 2002. High resolution palynological records from Atlantic Canada: regional Holocene paleoceanographic and paleoclimatic history [PhD dissertation]. Department of Earth Sciences, Dalhousie University, Halifax. 465 pages.

Levac E. 2003. Palynological records from Bay of Islands, Newfoundland: direct correlation Holocene paleoceanographic and climatic changes. Palynology 27:135-54.

Levac E. 2012. Eolian pollen transport towards Sable Island, Nova Scotia, Canada. IPC/IOPC 2012 Conference, August 23-30, Tokyo, Japan. Japanese Journal of Palynology 58:125.

Levac E, Lewis CFM, Miller AAL. 2011. The impact of the final Lake Agassiz flood recorded in northeast Newfoundland and northern Scotian shelves based on century-scale palynological data. In: Rashid H, Polyak L, Mosley-Thompson E, editors. Abrupt Climate
Change: Mechanisms, Patterns, and Impacts. Geophysical Monograph Series 193. Washington, DC: American Geological Union. p 139-59.

Lewis CFM, Miller AAL, Levac E, Piper DJW, Sonnichsen GV. 2012. Lake Agassiz outburst age and routing by Labrador Current and the $8.2 \mathrm{cal}$ ka cold event. Quaternary International 260:83-97.

Long A, Davis OK, DeLanois J. 1992. Separation and ${ }^{14} \mathrm{C}$ dating of pure pollen from lake sediments: nannofossil AMS dating. Radiocarbon 34(3):557-60.

McNeely R, Dyke AS, Southon JR. 2006. Canadian marine reservoir ages, preliminary data assessment: Open file 5049. Geological Survey of Canada. 3 p.

Mensing SA, Southon JR. 1999. A simple method to separate pollen for AMS radiocarbon dating and its application to lacustrine and marine sediments. Radiocarbon 41(1):1-8.

Mudie PJ. 1982. Pollen distribution in recent marine sediment, eastern Canada. Canadian Journal of Earth Science 19:729-47.

Mudie PJ, McCarthy FMG. 1994. Late Quaternary pollen transport processes, western North Atlantic: data from box models cross-margin and N-S transects. Marine Geology 118(1-2):79-105.

Pendea IF. 2011. Mid to late Holocene coastal landscape change in Eastern James Bay [PhD dissertation]. Department of Geography, McGill University, Montréal $154 \mathrm{p}$.

Pendea IF, Chmura GL. 2012. High resolution record of carbon accumulation rates during boreal peatland initiation. Biogeosciences 9:2711-7.

Pendea IF, Costopoulos A, Nielsen C, Chmura GL. 2010. A new shoreline displacement model for the last $7 \mathrm{ka}$ from eastern James Bay, Canada. Quaternary Research 73(3):474-84.

Regnell J, Everitt E. 1996. Preparative centrifugation: a new method for preparing concentrates suitable for radiocarbon dating by AMS. Vegetation History and Archaeobotany 5:201-5.

Reimer PJ, Reimer R. 2005. CALIBomb Radiocarbon Calibration [online]. Available: http://calib.qub.ac.uk/ CALIBomb/. Accessed 23 February 2013.

Reimer PJ, Brown TA, Reimer RW. 2004. Discussion: reporting and calibration of post-bomb ${ }^{14} \mathrm{C}$ data. Radiocarbon 46(3):1299-304.

Reimer PJ, Baillie MGL, Bard E, Bayliss A, Beck JW, Blackwell PG, Bronk Ramsey C, Buck CE, Burr GS, Edwards RL, Friedrich M, Grootes PM, Guilderson TP, Hajdas I, Heaton T, Hogg AG, Hughen KA, Kaiser KF, Kromer B, McCormac FG, Manning SW, Reimer RW, Richards DA, Southon JR, Talamo S, Turney CSM, van der Plicht J, Weyhenmeyer CE. 2009. IntCa109 and Marine09 radiocarbon age calibration curves, 0-50,000 years cal BP. Radiocarbon 51(4): 1111-50.

Richardson F, Hall VA. 1994. Pollen concentrate preparation from highly organic Holocene peat and lake deposits for AMS dating. Radiocarbon 36(3):407-12. 


\section{T Neulieb et al.}

Roe HM, van de Plassche O. 2005. Modern pollen distribution in a Connecticut saltmarsh: implications for studies of sea-level change. Quaternary Science Reviews 24(18-19):2030-49.

Sandercombe S. 2011. The marine record of abrupt climate change at Bay of Islands, Newfoundland [MSc thesis]. Department of Geography, McGill University, Montreal. $65 \mathrm{p}$.

Santos GM, Southon JR, Griffin S, Beaupré SR, Druffel ERM. 2007. Ultra small-mass AMS ${ }^{14} \mathrm{C}$ sample preparation and analyses at KCCAMS/UCI Facility. $\mathrm{Nu}$ clear Instruments and Methods in Physics Research B 259(1):293-302.

Shotyk W. 1996. Peat bog archives of atmospheric metal deposition: Geochemical evaluation of peat profiles, natural variations in metal concentrations, and metal enrichment factors. Environmental Reviews 4:149-83.

Southon J, Santos G Druffel-Rodriguez K, Druffel E, Trumbore S, Xu XM, Griffin S, Ali S, Mazon M 2004. The Keck Carbon Cycle AMS laboratory, University of California, Irvine: initial operation and a background surprise. Radiocarbon 46(1):41-9.
Stuiver M, Polach HA. 1977. Discussion: reporting of ${ }^{14} \mathrm{C}$ data. Radiocarbon 19(3):355-63.

Stuiver M, Reimer P, Reimer R. 2005. CALIB Manual [online]. Available: http://calib.qub.ac.uk/calib/manual/. Accessed 15 January 2013.

Stuiver M, Reimer PJ, Reimer R. 2012. Marine Reservoir Correction Database [online]. Available: http:// calib.qub.ac.uk/marine/. Accessed 15 January 2013.

Vasil'chuk AK. 2004. Radiocarbon dating of pollen and spores from ice wedges of the Yamal and Kolyma regions. Biology Bulletin 31:182-92.

Vasil'chuk AC, Kim JC, Vasil'chuk YK. 2004. The AMS dating of pollen from syngenetic ice-wedge ice. $\mathrm{Nu}$ clear Instruments and Methods in Physics Research B 223-224:645-9.

Wohlfarth B, Skog G, Possnert G, Holmquist B. 1998. Pitfalls in the AMS radiocarbon-dating of terrestrial macrofossils. Journal of Quaternary Science 13(2): 137-45.

Zhou W, Zhou J, Xiao JDD, Jull AJT. 1999. Preliminary study on radiocarbon AMS dating of pollen. Science in China Series D 42:524-30. 